\section{GM plants to be patented}

The top appeals board of the European Patent Office has ruled that transgenic plants may be patented under the European Patent Convention. In late December, the Patent Office's Enlarged Board of Appeal, considering an appeal by Novartis, ruled that article $53 \mathrm{~b}$ of the Convention, which excludes plant and animal varieties from patenting, does not apply to plant types in general that are modified by patentable biotechnological processes. Last September, a new Convention regulation came into effect that brought interpretation of article 53b in line with the European Union's directive on the patenting of biotechnology inventions concerning genetically modified organisms. But the Patent Office has been awaiting the Enlarged Board of Appeal's decision on the Novartis appeal before implementing the new rules (Nat. Biotechnol. 17, 842, 1999).

\section{Finance boom in 4Q, 1999}

At nearly $\$ 3$ billion, biotech financing in the last three months of 1999 was more than double the previous quarter, with initial public offerings (IPOs) raising $\$ 450.58$ million (up 306\%) and follow-ons $\$ 835.16$ million (up 454\%). According to Burrill \& Company (San Francisco, CA), stocks from companies with market caps of more than $\$ 1$ billion (top-tier) and those with market caps of between $\$ 300$ million and $\$ 1$ billion (mid-tier) increased over the quarter by an average of $62 \%$ and $52 \%$, respectively, while the smaller biotech companies increased 72\% - something Burrill ascribes to renewed investor interest in genomics companies (see "Biotechnology becomes the new dot com", p.140). The aggregate biotech market value shot up to $\$ 270$ billion by the end of 1999 from $\$ 191$ billion at the start of October. Dennis Purcell, Chase H\&Q's global head of life sciences, says that in 2000 the industry can look forward to an increasing number of IPOs, continued reliance by pharma on biotech for growth, continued FDA-industry cooperation, and availability of private equity to fund companies. But he says issues will include increasing stock market volatility, effects of pharmaceutical consolidation, and the impact of drug price/Medicare reform on investors.

Business and regulatory news briefs written by Emma Dorey, Julie Grisham, John Hodgson, KS Jayaraman, Eric Niiler, and Asako Saegusa.

\section{Japan steps up GMO tests}

Japan's Ministry of Health and Welfare (MHW; Tokyo) has announced that all foods containing genetically modified (GM) ingredients will undergo mandatory tests for potential health risks, beginning April 2001. Previously, such tests were carried out on a voluntary basis under a general outline issued by MHW, but now the ministry will specify enzymes and proteins that should be tested for to determine potential toxicity and allergenicity of GM organisms. MHW says it will halt the evaluation of all new GM foods until the new test is introduced. The ministry also intends to introduce mandatory labeling of GM foods that have passed safety approval, although it is still undecided as to whether the word "safety" should be included in such labels. Sources close to the ministry say the likeliest option for labeling would be "safety approved," although detailed safety measures are yet to be discussed. MHW's move complements that of the Ministry of Agriculture, Forestry, and Fisheries (MAFF; Tokyo), which decided last August to introduce mandatory labeling of all food products containing detectable GM ingredients beginning April 2001 (Nat. Biotechnol. 17, 837, 1999).

\section{NIH tech transfer rules}

The US National Institutes of Health's Office of Technology Transfer has released final guidelines for promoting greater sharing of research tools. The draft guidelines were set up in May 1999 to help recipients of NIH funding achieve balance between restrictions on research tools that are needed to protect proprietary interests and restrictions that can stifle dissemination of new discoveries and limit future research. The policy sets forth four principles: ensuring academic freedom and publication; minimizing administrative impediments to academic research; ensuring dissemination of research resources developed with $\mathrm{NIH}$ funds; and ensuring appropriate implementation of the Bayh-Dole Act, legislation passed in 1980 to encourage technology transfer. Universities and larger pharmaceutical companies have generally supported NIH's plan, but some believe it may encourage smaller biotech companies that acquire revenue from selling research tools-such as reagents, cell lines, proteins, and monoclonal antibodies - not to share materials with scientists that receive $\mathrm{NIH}$ funding. NIH says it has left "considerable discretion to recipients" in determining appropriate distribution of research tools.

\section{GMO roundup}

- Granada Food Services, the caterers at Monsanto UK's headquarters in High Wycombe, has told all its clients-including the multinational-that it will not supply food containing genetically modified soya or maize because of customer concerns. Monsanto employees and their guests can still eat genetically modified food at work, however: A notice at the restaurant at the company's Cambridge branch proudly proclaims that some foods may contain such ingredients.

- An anarchist group from Canada has put out detailed advice for activists on how to trash genetically engineered crops safely and get away with it. Tao Communications, which describes itself as a nonprofit national media organization that is active in analysis, media action, and publishing, has posted a 3000-word document called The Nighttime Gardener that is, in essence, a "how-to" guide for anti-biotechnology vandals. Tao has scoured the world to bring its readers helpful tips on destroying experimental crops. To avoid detection, for instance, it recommends that nighttime gardeners "wear a complete set of old clothes that can be easily discarded in dumpsters after gardening." To avoid health risks from herbicides, it advises that "GoreTex or rubber rain gear [cheaply purchased or easily stolen from Wal-Mart]. . . are necessary." It recommends the use of duct tape as an aid for smashing greenhouses silently but suggests that a sharp knife will do for plastic greenhouses. The best time to conduct this destructive hobby, apparently, is at night under a new moon when it is raining hard, but The Nighttime Gardener warns against very late excursions because country walks in the dead of night are more likely to attract attention.

Timing is important in order to maximize the impact of crop destruction: too early, Tao says, and there will be time to replant; too late, and you are just harvesting the crop for the biotechnology companies. The guide also points out that it is not necessary to destroy all of an experimental crop to make it worthless: "Destroying $50-75 \%$ of the research plants will call into question any data gathered." It also recommends taking out and redistributing the marker and identification tags from the plot. Finally, it notes that "computers, data files, clipboards with research information, and other documentation should be removed for our own research, or quietly destroyed." 